\title{
Species Diversity of Shallow Water Zoanthids (Cnidaria: Anthozoa: Hexacorallia) in Florida
}

\author{
James Davis Reimer, ${ }^{1,2}$ Colin Foord, ${ }^{3}$ and Yuka Irei ${ }^{4}$ \\ ${ }^{1}$ Molecular Invertebrate Systematics and Ecology Laboratory, Rising Star Program, Transdisciplinary Research Organization \\ for Subtropical Island Studies (TRO-SIS), University of the Ryukyus, Senbaru 1, Nishihara, Okinawa 903-0213, Japan \\ ${ }^{2}$ Marine Biodiversity Research Program, Institute of Biogeosciences, Japan Agency for Marine-Earth Science and \\ Technology (JAMSTEC), 2-15 Natsushima, Yokosuka, Kanagawa 237-0061, Japan \\ ${ }^{3}$ Coral Morphologic Aquaculture Research Lab, 800 NW 7th Avehve Miami, FL 33136, USA \\ ${ }^{4}$ Molecular Invertebrate Systematics and Ecology Laboratory, Graduate School of Engineering and Sciences, University of the Ryukyus, \\ Senbaru 1, Nishihara, Okinawa 903-0213, Japan
}

Correspondence should be addressed to James Davis Reimer, jreimer@sci.u-ryukyu.ac.jp

Received 22 March 2012; Accepted 25 May 2012

Academic Editor: Pei-Yuan Qian

Copyright (C) 2012 James Davis Reimer et al. This is an open access article distributed under the Creative Commons Attribution License, which permits unrestricted use, distribution, and reproduction in any medium, provided the original work is properly cited.

\begin{abstract}
Shallow water zooxanthellate zoanthids are a common component of the coral reef ecosystems of the Caribbean. Despite this, their species diversity remains poorly understood. In this study, collected Palythoa, Zoanthus, Isaurus, and Terrazoanthus specimens from the waters of Florida were phylogenetically examined to obtain a better understanding of zoanthid species diversity in the Caribbean. Surprisingly, the results from analyses utilizing three DNA markers (mitochondrial 16S ribosomal DNA, cytochrome oxidase subunit I, and the internal transcribed spacer of ribosomal DNA) showed the presence of at least eleven species, of which up to four appear undescribed. Additionally, the presence of the genus Terrazoanthus in the Caribbean was confirmed for the first time. Attempts to match phylogenetic species or clades with original literature were hampered by vague and short original descriptions, and it is clear that for Atlantic Palythoa and Zoanthus species an in-depth and multidisciplinary investigation is needed to reconcile recent phylogenetic results such as in this study with traditional taxonomy. Furthermore, most shallow water zoanthid species from Florida were observed to have close, sister-species relationships with previously investigated species in the Pacific Ocean. These results indicate that many brachycnemic zoanthid species likely had a Caribbean-Pacific distribution until the formation of the Isthmus of Panama. However, due to inadvertent redescriptions, overall species diversity in these two common genera is likely much lower than literature indicates.
\end{abstract}

\section{Introduction}

The coral reef ecosystems of Florida are the only large area of shallow water coral reefs in the continental United States, and as such have been the subject of studies investigating their ecology [1], biodiversity, and recent history [2]. Despite this, the region has undergone rapid degradation in terms of live coral coverage due to coral bleaching [3] and disease [4], among other stressors, with corresponding large losses of live coral cover $[5,6]$.

One of the most common groups of organisms on the reefs of Florida and the Greater Caribbean is the zoanthids. In fact, some zoanthids (Anthozoa: Hexacorallia) are so common that a portion of the shallow intertidal zone has been called the "Zoanthus zone" [7]. Like many reef-building hard corals, most shallow tropical and subtropical zoanthids are in symbiosis with Symbiodinium (=zooxanthellae) species, endosymbiotic, photosynthetic dinoflagellates. Despite being an obvious and ubiquitous part of the Caribbean coral reef ecosystem, the taxonomy and diversity of zoanthids worldwide are poorly understood, and even species identification remains problematic [8-10]. However, recent research utilizing different mitochondrial and nuclear DNA markers has allowed researchers to begin to reassess zoanthid species identification $[9,10]$. In this study, we apply these molecular methods to investigate the diversity of shallow water zoanthids in Florida. Phylogenetic species or species groups were then compared with original species descriptions in 
an attempt to formally identify specimens. Our results (1) demonstrate the utility of molecular methods in zoanthid identification, (2) indicate that previously undescribed zoanthid diversity may be common in the Caribbean Sea despite overall diversity being likely lower than in the taxonomic literature, and (3) highlight the considerable taxonomic problems of shallow water brachycnemic zoanthids in the Caribbean Sea.

\section{Materials and Methods}

2.1. Specimen Collection. This study primarily focused on zoanthids from the suborder Brachycnemina, which consists of the families Sphenopidae, Zoanthidae, and Neozoanthidae, and we did not collect specimens from Parazoanthidae or Epizoanthidae (suborder Macrocnemina). However, a specimen of Hydrozoanthidae (Macrocnemina), specifically nonepizoic species (resembling Terrazoanthus sp.), was collected. All specimens were collected by snorkeling, and collectively we refer to these specimens as "shallow water zoanthids" in this study.

Specimens from Florida $(n=20)$ were collected between December 2009 and January 2010 by SCUBA or snorkeling (see Table 1 for collection details). Two additional specimens were collected from the aquarium trade (Table 1). Specimens were collected, placed in labeled, sealable plastic cups, and subsequently photographed in vitro once acclimated in an aquaculture facility in Miami (Figure 1). Preservation was carried out using 99\% analytical grade ethanol.

\subsection{DNA Extraction, PCR Reactions, and DNA Sequencing.} Genomic DNA was extracted from portions of specimens by following a guanidine extraction protocol as described in [11]. PCR amplification using template genomic DNA was conducted using HotStarTaq DNA polymerase (Qiagen) according to the manufacturer's instructions. An approximately 900 base pair fragment of mitochondrial 16S ribosomal DNA (mt 16S rDNA) was amplified using the primer set $16 \mathrm{SbmoH}$ [10] and 16Sant0a [11]. An approximately 460 base pair portion of cytochrome oxidase subunit 1 (COI, including the common "barcode" region amplified with universal primers) was amplified using the zoanthidspecific primer COIZoanF [11] and the universal reverse primer HCO2198. The nuclear internal transcribed spacer region (ITS-rDNA, including ITS-1, 5.8S rDNA, and ITS2; approximately 600-650 base pairs) was amplified using the primers Zoan-F and Zoan-R [12, 13]. Amplification conditions followed [10-14], and, for each DNA marker, respectively.

Amplified products were visualized by $1.0 \%$ agarose gel electrophoresis, and positive PCR products were treated with Exonuclease I and Shrimp Alkaline Phosphatase (Takara) prior to sequencing reactions. Direct sequencing of each marker in both directions was performed by MacroGen Japan (Tokyo).

2.3. Phylogenetic Analyses. New sequences obtained in this study were deposited in GenBank (accession numbers JX119120-JX119168). Sequences of all three DNA markers were aligned with publically available sequences of Palythoa (family Sphenopidae), Zoanthus, Acrozoanthus, and Isaurus (Zoanthidae), and Hydrozoanthus and Terrazoanthus (Hydrozoanthidae), with sequences from Parazoanthidae utilized as outgroups for $\mathrm{mt} 16 \mathrm{~S} \mathrm{rDNA}$ and COI, as the monophylies of these two families and their sister-group relationship has previously been demonstrated [10]. The identity of zoanthid sequences in GenBank is generally believed to be accurate, although asides from some Pacific species' sequences, sequences are not from topotypic specimens. For COI, two alignments were made, a shorter alignment with more taxa ("COI short"), and a longer alignment with less taxa ("COI long"), as many publically available COI sequences are shorter (e.g., <350 b.p.) than the COI sequences acquired in this study. Thus, the "short" alignment has more different taxa, while the "long" alignment has less taxa but longer sequences. For the ITSrDNA alignment, Hydrozoanthus (but not Terrazoanthus) sequences were utilized as the outgroup. For the mt $16 \mathrm{~S}$ rDNA alignment, a base alignment from [11] was used to guide alignment of sequences, while for ITS-rDNA, alignments were guided by alignments from [12] for Palythoa and from [13] for Zoanthus, with additional secondary structure information [15] utilized.

All alignments were inspected by eye and any ambiguous sites (e.g., only sites with double or ambiguous peaks, $n=$ 0 to 1 /alignment) in the alignments were removed from the dataset prior to phylogenetic analyses. Four alignment datasets were generated: (1) 603 sites of 46 sequences (mt $16 \mathrm{~S}$ rDNA), (2) 461 sites of 28 sequences ("COI long"), (3) 280 sites of 35 sequences ("COI short"), and (4) 1013 sites of 32 sequences (ITS-rDNA). Alignment data sets are available from the corresponding author.

For the phylogenetic analyses of the data sets, the same methods were independently applied. Alignments were subjected to analyses with the maximum likelihood (ML) with PhyML [16] and neighbour-joining (NJ) methods. PhyML was performed using an input tree generated by BIONJ with the general time-reversible model [17] of nucleotide substitution incorporating a discrete gamma distribution (eight categories) (GTR+). The discrete gamma distribution and base frequencies of the model were estimated from the dataset. PhyML bootstrap trees (1000 replicates) were constructed using the same parameters as the individual ML tree. The distances were calculated using a Kimura's 2-parameter model [18]. Support for NJ branches was tested by bootstrap analysis [19] of 1000 replicates. CLC Free Workbench 3.0 (Aarhus, Denmark) was used for NJ phylogenetic analyses (1000 replicates).

2.4. Specimen Identification. Specimens were identified using combined molecular, morphological, and ecological data from previous literature. For morphology, colony shape, polyp size and structure, and comparisons with original descriptions were undertaken. For ecological data, specimens' habitats and depths were taken into account. Acquired DNA sequences in this study were compared against previously obtained sequences in GenBank. When morphological date for specimens did not fit perfectly with described 


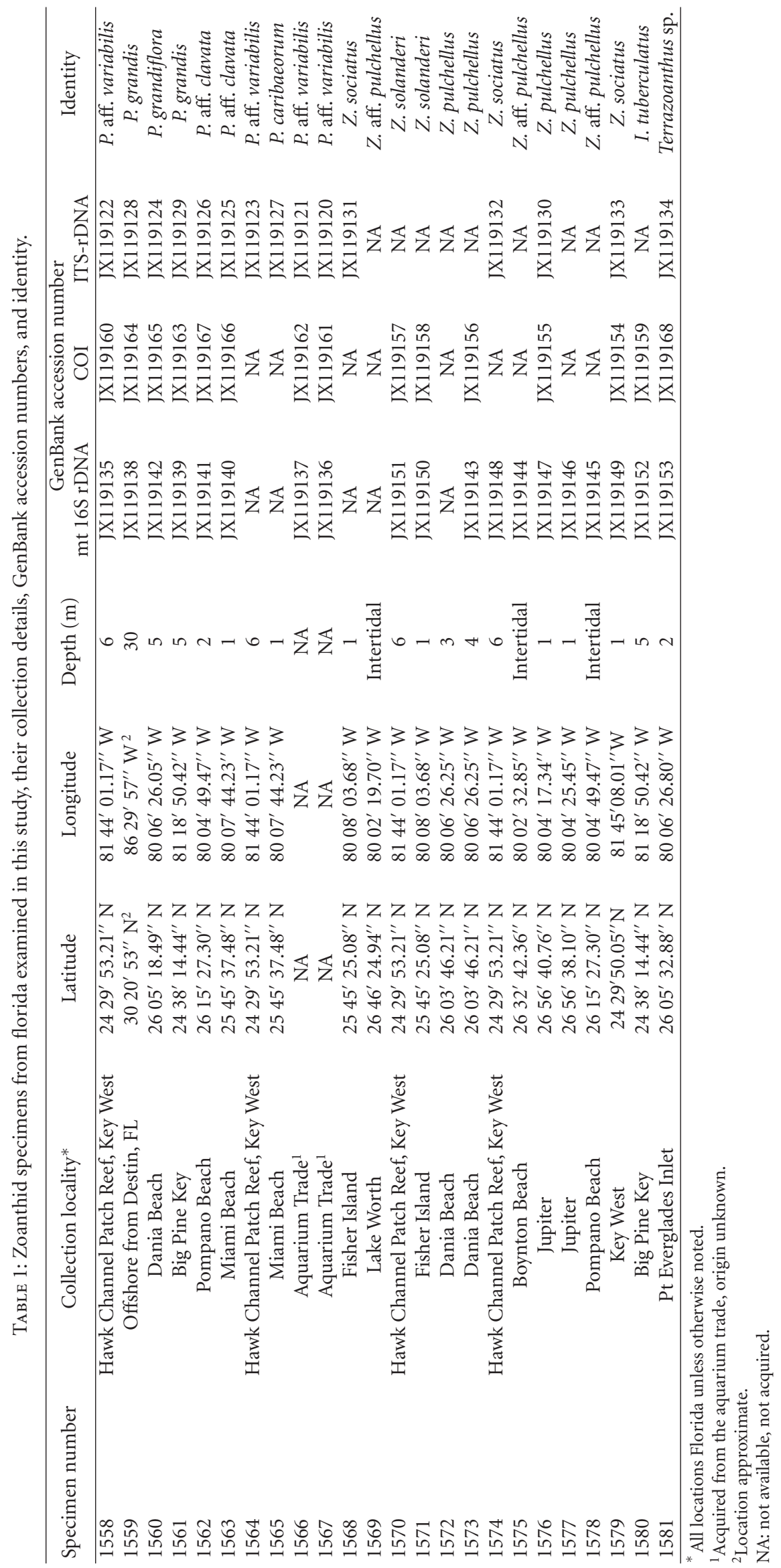




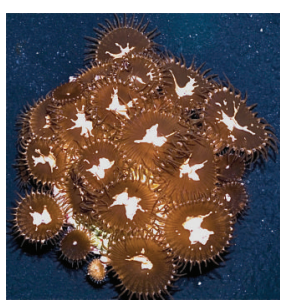

(a)

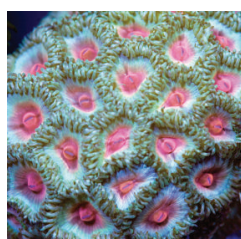

(f)

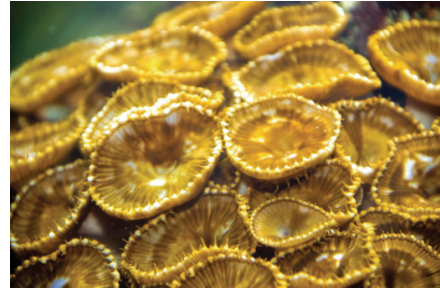

(b)

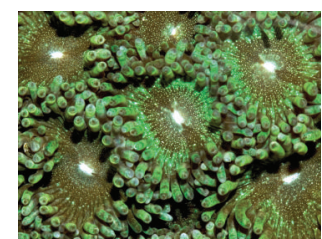

(g)

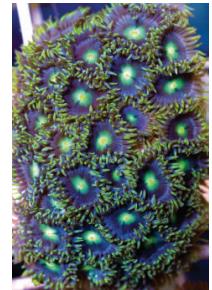

(c)

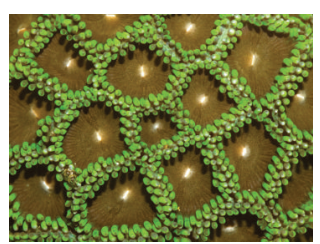

(h)

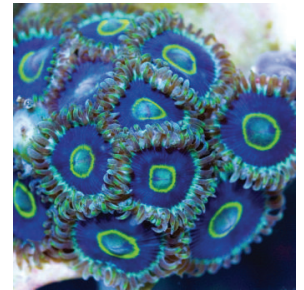

(d)

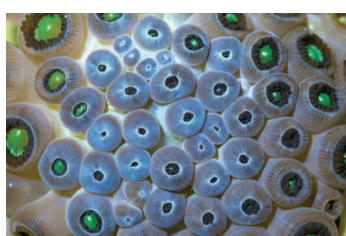

(e)

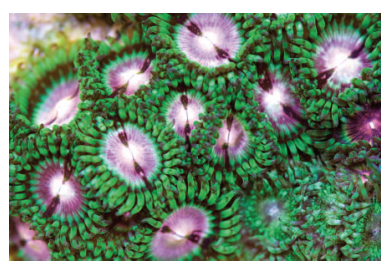

(i)

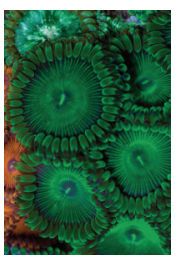

(j)

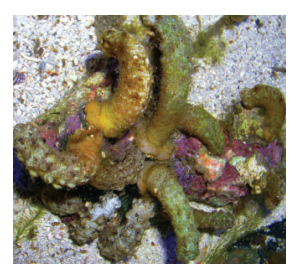

(k)

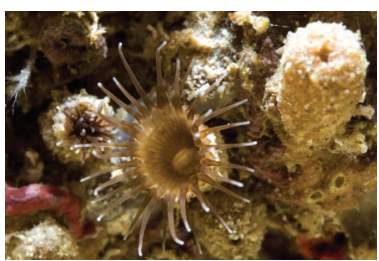

(1)

Figure 1: Zoanthid specimens from Florida examined in this study. (a) Palythoa aff. variabilis 1558; (b) Palythoa grandis specimen 1559; (c) Zoanthus sociatus specimen 1579 and (d) specimen 1574; (e) Zoanthus aff. pulchellus specimen 1575 and (f) specimen 1578; (g) Zoanthus pulchellus specimen 1572, (h) specimen 1576, and (i) specimen 1577; (j) Zoanthus solanderi specimen 1571; (k) Isaurus tuberculatus specimen 1580; (1) Terrazoanthus sp. specimen 1581. For collection details refer to Table 1.

species, we then identified species or species groups utilizing "aff." or "cf." accordingly. All relevant previous zoanthid taxonomic literature was consulted [7, 20-71].

\section{Results}

3.1. Mitochondrial 16S Ribosomal DNA. mt 16S rDNA sequences from specimens in this study were placed within three large clades, corresponding to the families Sphenopidae, Zoanthidae, and Hydrozoanthidae (Figure 2(a)). Each of these large family-level clades was generally well supported in phylogenetic analyses (e.g., $\mathrm{ML}=89 \%, 98 \%, 80 \%$, resp.).

Sequences from eight specimens were within the Sphenopidae clade. Sequences from 1558, 1566, and 1567 were identical to each other and were most closely related to Palythoa heliodiscus [66] sequence AB219224 from Japan. These four sequences together formed a well-supported subclade $(\mathrm{ML}=98 \%, \mathrm{NJ}=98 \%)$. Two other sequences $(1559$, 1561), although identical to each other, did not match with any previously reported Palythoa sequence and were in an unresolved position basal to other Palythoa. The remaining large subclade, which was moderately supported $(\mathrm{ML}=84 \%$, NJ $=75 \%)$, contained the remaining Palythoa sequences. Sequences from 1562 and 1563 were identical to each other, and to two sequences from Palythoa sp. "sakurajimensis" sensu Reimer et al. [12] (DQ997842, DQ997863) in an unresolved position. The sequence from specimen 1560 was identical to one from Palythoa mutuki Haddon and Shackleton 1891, from Japan (AB219225) (ML $=73 \%, \mathrm{NJ}=$ 91\%).

In the Zoanthidae clade, the sequence from specimen 1580 was identical to Isaurus tuberculatus Gray 1828 sequences from Japan (EF452253) and Cape Verde (HM130475), and these three sequences formed a well-supported Isaurus clade $(\mathrm{ML}=99 \%, \mathrm{NJ}=96 \%)$. Sequences from specimens 1570 and 1571 were identical and formed a clade (ML = $90 \%, \mathrm{NJ}=88 \%$ ) and were close to and derived from a sequence from Zoanthus gigantus Reimer and Tsukahara 2006 ([72]; AB219192) from Japan. Sequences from 1574 and 1579 were identical to previously reported sequences from Z. sansibaricus Carlgren 1900 [73] (AB219187) in Japan and Z. sociatus (Ellis 1768) (HM130476) from Costa Rica, and similar to an additional $Z$. sociatus (HM130477) sequence from Costa Rica, and these sequences formed a wellsupported clade $(\mathrm{ML}=97 \%, \mathrm{NJ}=86 \%)$. Most remaining Zoanthidae sequences asides from $Z$. praelongus (EF452256) and Acrozoanthus (AY996947) formed a well-supported subclade $(\mathrm{ML}=95 \%, \mathrm{NJ}=93 \%)$. Within this subclade, two sequences $(1575,1578)$ were identical to previously sequences from $Z$. kuroshio Reimer and Ono 2006 in Japan (AB219191) and Z. aff. pulchellus (Duchassaing and Michelotti 1860) from Cape Verde (HM130471). Two sequences $(1576,1577)$, identical to each other, differed by one base substitution from the former four sequences, and one 


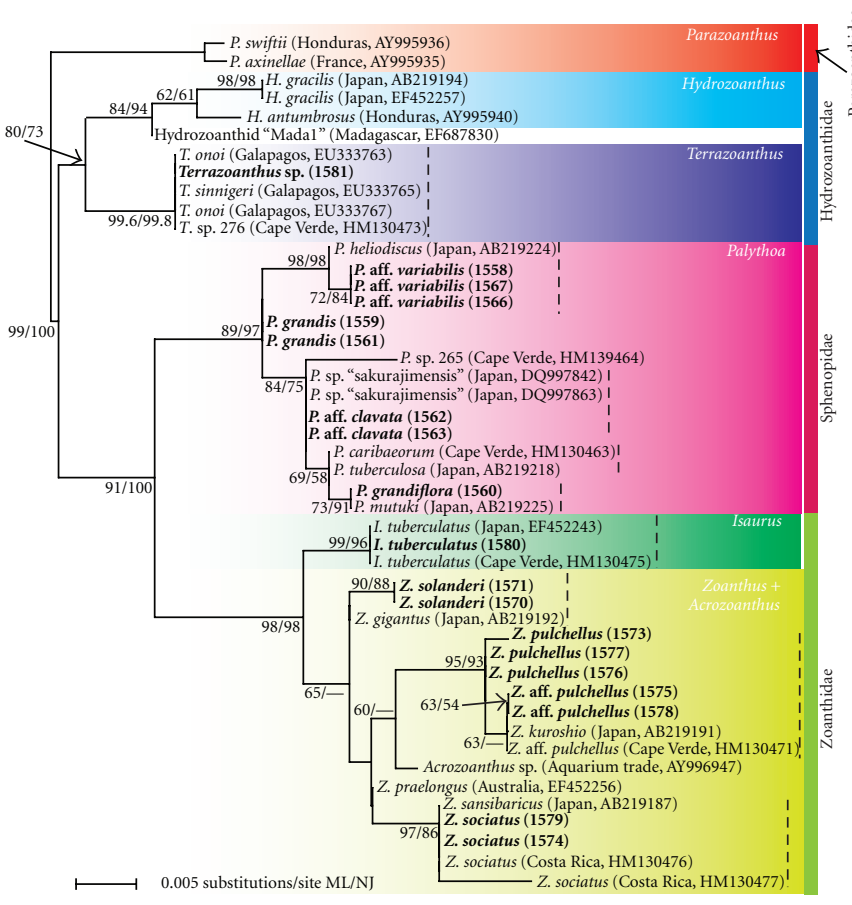

(a)

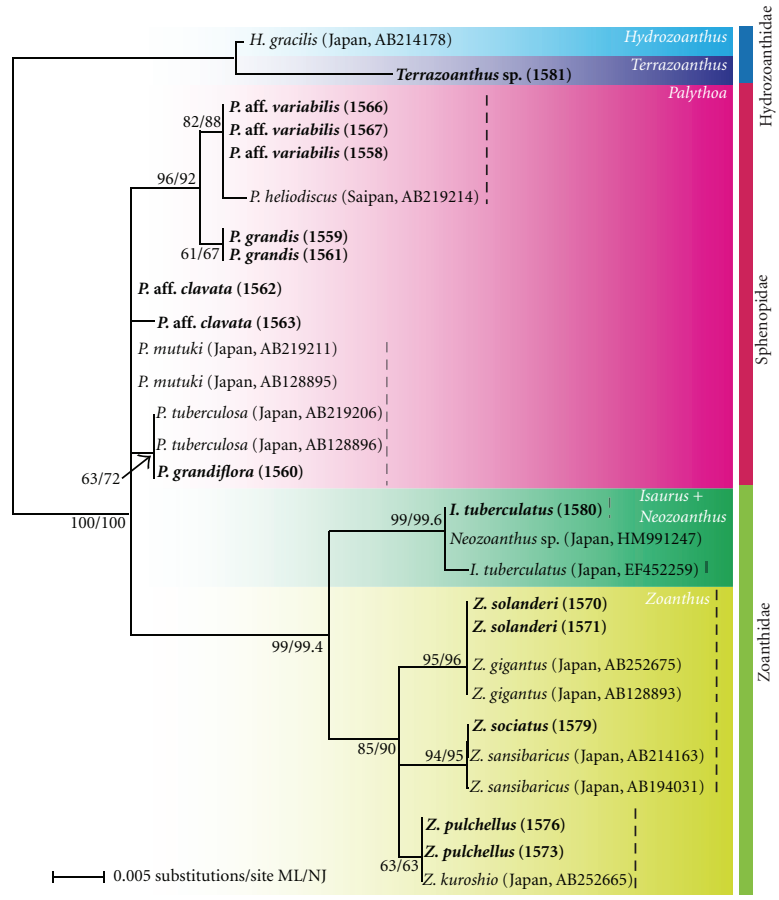

(b)

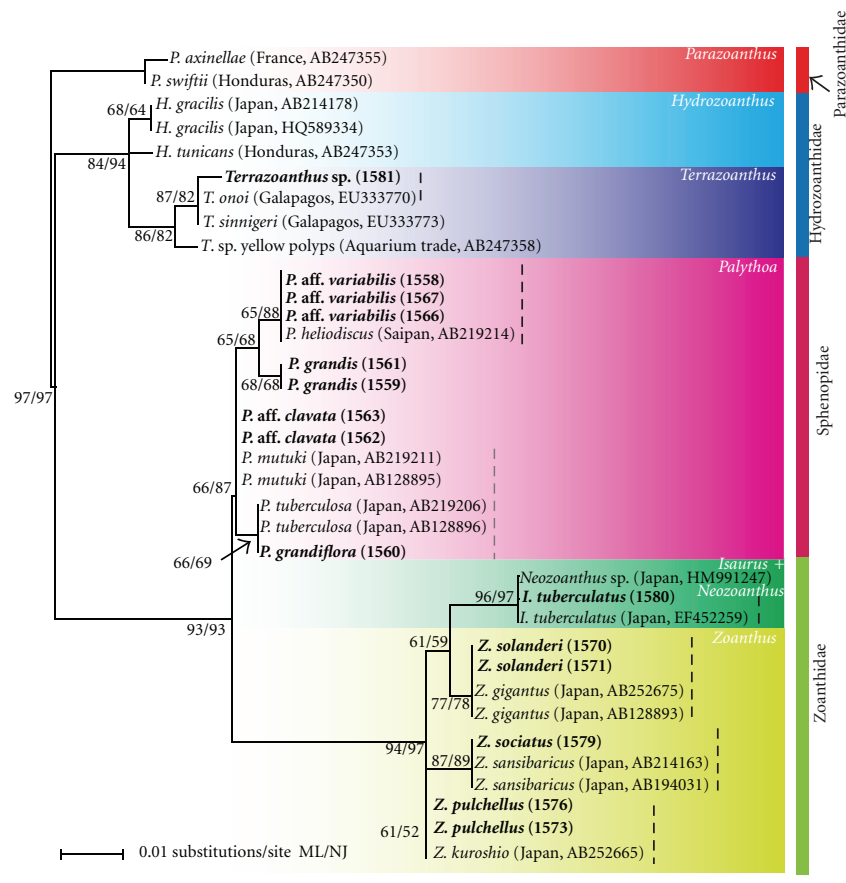

(c)

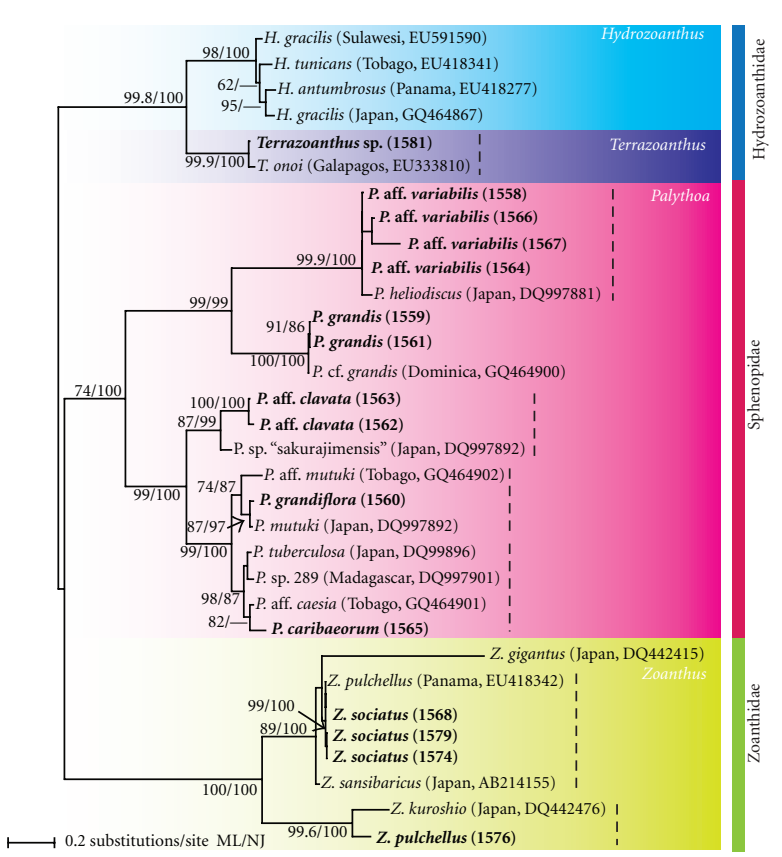

(d)

FIgURE 2: Maximum likelihood trees of (a) mitochondrial $16 \mathrm{~S}$ ribosomal DNA sequences, (b) "long" alignment of mitochondrial cytochrome oxidase subunit I (COI), (c) "short" alignment of COI, and (d) internal transcribed spacer of ribosomal DNA (ITS-rDNA) sequences. Novel sequences from specimens in this study represented in bold. Sequences/species names from previous studies are in regular font with species name, location, and GenBank accession numbers. Values at branches represent maximum likelihood (ML) and neighborjoining (NJ) bootstrap probabilities, respectively. Atlantic/Pacific sister species groups are represented by dark dashed lines, groups for which resolution in the phylogenetic tree are weak by gray dashed lines. For specimen information see Table 1. 
additional sequence (1573) was different from these two sequences by three additional base pairs.

Within the Hydrozoanthidae clade, two subclades were observed, one corresponding to genus Hydrozoanthus ( $\mathrm{ML}=$ $84 \%, \mathrm{NJ}=94 \%$ ) and one to genus Terrazoanthus ( $\mathrm{ML}=$ $99 \%, \mathrm{NJ}=99 \%)$. The mt $16 \mathrm{~S}$ rDNA sequence from specimen 1581 was identical to previously reported sequences from T. onoi Reimer and Fujii 2010 [74] (EU333762, EU333767), T. sinnigeri Reimer and Fujii 2010 (EU333765) in the Galapagos, and an unidentified Terrazoanthus species from Cape Verde (HM130473).

3.2. Cytochrome Oxidase Subunit I. The topologies of the "long" and "short" maximum likelihood trees were generally identical with only a few inconsistencies (Figure 2(b), 2(c), resp.). The largest difference was in the families Hydrozoanthidae and Parazoanthidae, as there were more taxa in the "short" alignment ( $n=9$ as opposed to $n=2$ in the "long" tree). As well, bootstrap values were generally higher in the "long" tree (compare values at nodes in Figures 2(b) and 2(c)). Furthermore, the placement of Isaurus and Neozoanthus was inconsistent (Figures 2(b), and 2(c)).

3.2.1. "Short" COI Alignment. As in the mt $16 \mathrm{~S}$ rDNA tree, there were three generally well-supported family-level clades, corresponding to Sphenopidae $(\mathrm{ML}=66 \%, \mathrm{NJ}=87 \%)$, Zoanthidae $(\mathrm{ML}=94 \%, \mathrm{NJ}=97 \%)$, and Hydrozoanthidae $(\mathrm{ML}=84 \%, \mathrm{NJ}=94 \%)($ Figure $2(\mathrm{c}))$.

Eight novel sequences from this study were within the Sphenopidae clade. Sequences from specimens 1558, 1566, and 1567 were identical to a sequence from $P$. heliodiscus from Saipan $(\mathrm{AB} 219214)(\mathrm{ML}=65 \%, \mathrm{NJ}=88 \%)$. This subclade was sister to a subclade consisting of the two identical sequences 1559 and $1561(\mathrm{ML}=68 \%, \mathrm{NJ}=$ 68\%). Sequences from 1562 and 1563 were identical to two sequences from P. mutuki from Japan (AB219211, $\mathrm{AB} 128895)$, and these four sequences were unresolved in a position basal to both the P. heliodiscus and $1559+1561$ subclades, and a $P$. tuberculosa + specimen 1560 subclade $(\mathrm{ML}=66 \%, \mathrm{NJ}=69 \%)$.

Within the Zoanthidae clade, the sequence from 1580 was identical to another Isaurus sequence from Japan (EF452259) and also to a sequence from Neozoanthus sp. in Japan (HM991247), and these three sequences formed a very well-supported subclade $(M L=96 \%, N J=97 \%)$. Sequences for specimens 1570 and 1571 were identical to sequences from Z. gigantus in Japan (AB128893, AB252675), and these four sequences formed a moderately well-supported subclade sister to the Isaurus subclade $(\mathrm{ML}=77 \%, \mathrm{NJ}=$ $78 \%$ ). The sequence from specimen 1579 was identical to two sequences from $Z$. sansibaricus in Japan, forming a wellsupported subclade $(\mathrm{ML}=87 \%, \mathrm{NJ}=89 \%)$. Finally, 1573 and 1576 's sequences were identical to a sequence from $Z$. kuroshio in Japan (AB252665).

The novel sequence from specimen 1581 clustered with three other previously reported Terrazoanthus spp. sequences and formed a well-supported subclade $(\mathrm{ML}=86 \%, \mathrm{NJ}=$ $82 \%)$.
3.2.2. "Long" COI Alignment. Results from the "long" COI phylogenetic analyses were basically the same as reported above for the "short" COI alignment. The only major difference was that the sequence from 1581 was clustered with the only other Hydrozoanthidae sequence in the alignment, $H$. gracilis in Japan (AB214178), as the outgroup (Figure 2(b)), but this is to be expected given the reduction of Hydrozoanthidae sequences in this tree compared with the "short" tree. Furthermore, some small sequence differences not seen in the short COI tree were present (e.g., between $P$. heliodiscus and sequences from specimens 1566, 1567, and 1568).

\subsection{Internal Transcribed Spacer Region of Ribosomal DNA.} Several Zoanthus specimens (1569, 1570, 1571, 1572, 1575, 1577, and 1578) did not amplify, and the single Isaurus specimen also did not amplify (1580), despite repeated attempts using all previously reported zoanthid ITS-rDNA primers $[12,13,69]$, similar to as in previous reports for both Zoanthus [13] and Isaurus [75]. However, we could obtain PCR products for the majority of specimens, and their resulting ITS-rDNA sequences had no double peaks.

Topology of the phylogenetic tree for the ITS-rDNA alignment (Figure 2(d)) was generally similar to the topologies of the mt $16 \mathrm{~S}$ rDNA and COI trees reported above, with more resolution within the species-group level clades. Again, three major family-level clades were seen, corresponding to Sphenopidae $(\mathrm{ML}=74 \%, \mathrm{NJ}=100 \%)$, Zoanthidae $(\mathrm{ML}=$ $100 \%, \mathrm{NJ}=100 \%)$, and Hydrozoanthidae $(\mathrm{ML}=99 \%, \mathrm{NJ}=$ $100 \%)$.

Within Sphenopidae, two large subclades were formed. One subclade contained $P$. heliodiscus, $P$. cf. grandis (Verrill 1900), and related sequences, and the other subclade contained $P$. sp. "sakurajimensis", $P$. aff. mutuki, $P$. mutuki, $P$. aff. caesia Dana 1846, P. tuberculosa (Esper 1791) [76], and related sequences. Support for both large subclades was high $(\mathrm{ML}=99 \%, \mathrm{NJ}=99 \% ; \mathrm{ML}=99 \%, \mathrm{NJ}=100 \%$; resp. $)$.

Within the first large subclade, two smaller subclades were present. Four sequences (1558, 1564, 1566, and 1567) were slightly different but clustered with $P$. heliodiscus from Japan (DQ997881) and formed an almost completely supported subclade $(\mathrm{ML}=99.9 \%, \mathrm{NJ}=100 \%)$. This subclade was sister to another subclade that contained a previously reported sequence from $P$. cf. grandis from Dominica ([70]; GQ464900) and sequences from 1559 and 1561. This subclade was completely supported $(\mathrm{ML}=100 \%, \mathrm{NJ}=$ $100 \%)$.

Within the second large subclade, sequences from 1562 and 1563 formed a grouping $(\mathrm{ML}=100 \%, \mathrm{NJ}=100 \%)$ that together with a sequence from $P$. sp. "sakurajimensis" (DQ997887) formed a subclade ( $\mathrm{ML}=87 \%, \mathrm{NJ}=99 \%$ ). The sequence from 1560 was closely related to that of $P$. mutuki from Japan (DQ997892) and P. aff. mutuki from Tobago (GQ464902) formed a moderately supported subclade $(\mathrm{ML}=74 \%, \mathrm{NJ}=87 \%)$. The ITS-rDNA sequence from 1565 was contained within a well-supported $P$. aff. caesia (Tobago, GQ464901), P. tuberculosa (Japan, DQ997896) and related sequences subclade $(\mathrm{ML}=98 \%, \mathrm{NJ}=87 \%)$. 
Within Zoanthidae, three specimens' sequences (1568, 1574 , and 1579) formed a small clade $(\mathrm{ML}=99 \%, \mathrm{NJ}=$ $100 \%)$ with a previously reported sequence from $Z$. pulchellus from Panama (EU418342), while one sequence from specimen (1576) formed a clade with a sequence from $Z$. kuroshio in Japan (DQ442476) ( $\mathrm{ML}=99.6 \%, \mathrm{NJ}=100 \%)$.

Within Hydrozoanthidae, two subclades were seen. One highly supported subclade corresponded to the genus Hydrozoanthus $(\mathrm{ML}=98 \%, \mathrm{NJ}=100 \%)$, while the other subclade was made up of sequences from T. onoi (EU333810) and specimen $1581(\mathrm{ML}=99.9 \%, \mathrm{NJ}=100 \%)$.

3.4. Specimen Identification. Overall, 11 species groups were confirmed to exist from the molecular data analyses. The taxonomic identification of each species group is as follows.

(1) Zoanthus sociatus (Ellis 1768) [20]. Specimens: 1568, 1574 , and 1579.

Although the original description is short, the sum of subsequent literature $[7,21,23,30,39,40,42,44,45,54$, $55,58,60]$ describes $Z$. sociatus with polyps of approximately $5 \mathrm{~mm}$ in diameter with a slightly larger oral disk, polyp height to $25 \mathrm{~mm}, 48$ to 60 short tentacles, with a green, blue, or yellow oral disk sometimes with patterning, with stoloniferous colonies found mostly in shallow water or the intertidal zone. Other former species synonymized with $Z$. sociatus are the Caribbean Z. flos-marinus Duchassaing and Michelotti 1860, Z. poriticola Pax, 1910, and Z. proteus Verrill, 1900 (for a complete taxonomic review, refer to above literature). It is likely Z. nobilis Duchassaing and Michelotti 1860 is also within this species, although there is some questions as to whether it is instead a synonym of $Z$. solander $i$ (see $[44,46])$.

In this study, both mtDNA markers grouped these specimens in a clade together with previously acquired $Z$. sociatus sequences from Costa Rica as well as $Z$. sansibaricus sequences from Japan. ITS-rDNA results showed all three specimens forming their own clade together with $Z$. pulchellus (EU418342) from Panama, closely related to Z. sansibaricus from Japan. These specimens' shallow distribution ( 1 to 6 meters; Table 1) and morphology (Figures 1(c), and 1(d)) generally matched with the description of $Z$. sociatus given above, and these specimens were assigned to this species (but see Section 4).

(2) Zoanthus pulchellus (Duchassaing and Michelotti 1860) [30]. Specimens: 1572, 1573, 1576, and 1577.

Although the original description is short, it and subsequent literature [37, 40, 42, 44, 45, 55] describe $Z$. pulchellus with polyps of approximately $4-6 \mathrm{~mm}$ in diameter with a slightly larger oral disk, polyp height 4 to over $30 \mathrm{~mm}$, 50 to 60 short tentacles, with a green or yellow oral disk sometimes with pink, brown, or yellow patterning, and encrusting colonies with a lamellar coenenchyme found mostly in shallow water, and not intertidal as seen sometimes in $Z$. sociatus. Other former species synonymized with $Z$. pulchellus are the Caribbean $Z$. nymphaeus Duchassaing and Michelotti 1860, Z. auricula Duchassaing and Michelotti 1860, Z. dubius Lesueur 1817, and Z. anduzii Duchassaing and Michelotti 1860 (for a complete taxonomic review, refer to above literature). Additionally, Zoanthus sp. 1 (Erdmann,
1886) [77], as well as $Z$. flos-marinus in [39], and some $Z$. proteus in [40] and $Z$. dubius sensu Duerden [37] are likely $Z$. pulchellus.

In this study, analyses of COI and ITS-rDNA sequences placed three specimens (one additional specimen, 1572, did not amplify successfully) in a group together with but not identical to $Z$. kuroshio sequences from Japan. As well, these specimens' $\mathrm{mt}$ 16S rDNA sequences were slightly distinct from sequences of specimens 1575 and 1578, as well as previously reported Z. kuroshio (AB219191) and $Z$. aff. pulchellus (HM130471) sequences. These specimens' distribution (1 to 4 meters; Table 1) and morphology (Figures $1(\mathrm{~g})-1(\mathrm{i})$ ) generally matched with the description of $Z$. pulchellus given above, and these specimens were assigned to $Z$. pulchellus.

(3) Zoanthus aff. pulchellus. Specimens: 1569, 1575, and 1578 .

DNA sequences from two specimens $(1575,1578)$ were only amplifiable for mt $16 \mathrm{~S} \mathrm{rDNA}$, and despite repeated attempts the other two markers did not amplify, while no amplifications were successful for specimen 1569. A similar situation has been seen previously with $Z$. kuroshio from Japan, in which ITS-rDNA did not amplify using usual zoanthid-specific markers [13]. mt 16S rDNA sequences for these two specimens were identical to both Z. kuroshio (AB219191) and Z. aff. pulchellus (HM130471) from Cape Verde. Morphologically, specimens had a more developed coenenchyme than $Z$. sociatus, similar to as seen in $Z$. aff. pulchellus from Cape Verde sensu Reimer et al. [71], and had brightly colored oral disks of green or pink (Figures 1(e), and $1(\mathrm{f})$ ).

Furthermore, specimens were found only in the intertidal zone, different from the described habitat of $Z$. pulchellus, and similar to as observed in in Z. aff. pulchellus [71], and due to the slightly different morphology and ecology as well as small but identical differences in $\mathrm{mt}$ 16S rDNA sequences from those of $Z$. pulchellus specimens above, we have designated specimens 1575 and 1578 as $Z$. aff. pulchellus. As this designation is based on only mt $16 \mathrm{~S}$ rDNA and morphology/ecology, it is hoped that future in-depth investigation with more specimens and phylogenetic data will confirm this identification.

(4) Zoanthus solanderi Lesueur 1817 [23]. Specimens: 1570 , and 1571.

The original description [23] and subsequent literature $[7,37,40,54,55,58,60,63]$ describe $Z$. solanderi as larger than other Caribbean Zoanthus species, with polyps of approximately 8 to $10 \mathrm{~mm}$ in diameter with a slightly larger oral disk, polyp height to $50 \mathrm{~mm}, 50$ to 60 short tentacles, with a blue, bright orange, dark brown, dark green, or bright blue oral disks sometimes with "white fleck" patterning, with stoloniferous colonies found mostly on the surf zone, below $Z$. sociatus. Often polyps have white markings around the mouth when semi-contracted [37]. It may be that $Z$. nobilis Duchassaing and Michelotti 1860 is also within Z. solanderi, although there is some questions as to whether it is instead a synonym of $Z$. sociatus [44, 45]. As well, $Z$. sociatus in [52] has been thought in fact to have been $Z$. solanderi [7]. 
In this study, DNA sequences from mtDNA molecular markers placed these specimens in a group together with previously acquired $Z$. gigantus sequences from Japan. These specimens' shallow distribution ( 1 to 6 meters; Table 1 ) and morphology (Figure 1(j)) fit with the description of $Z$. solanderi given above, and these specimens were assigned to Z. solanderi.

(5) Palythoa caribaeorum (Duchassaing and Michelotti, 1860) [30]. Specimen: 1565.

The original description [30] and subsequent literature $[7,31,32,42,45,47,48,53-55,58,60,63,64,66]$ describe P. caribaeorum as cream, brown, or yellow in color, with polyps deeply embedded in a well-developed, sandencrusted coenenchyme (="immersae", [45]). Polyps have 28 to 34 tentacles, and this species is common throughout the Caribbean.

In this study, DNA sequences from ITS-rDNA placed specimen 1565 in a subclade together with previously acquired $P$. aff. caesia sequences from Tobago, and this subclade was within a larger clade consisting of $P$. tuberculosa Esper 1791, P. mutuki and other specimens from the Pacific and Atlantic. It should be noted that P. caesia Dana 1846 is described from Fiji and Australia, and not the Caribbean. Based on morphological and molecular results, this specimen was assigned to $P$. caribaeorum. 1560.

(6) Palythoa grandiflora (Verrill, 1900) [40]. Specimen:

Caribbean Palythoa species with polyps somewhat or completely clear of their coenenchyme ("intermediate" or "liberae" in [45]) have a particularly long and confused taxonomic history, with at least 39 binomens in the literature. Specimen 1560 morphologically best fit with P. grandiflora Verrill 1900, which is described in literature as having polyps $15-20 \mathrm{~mm}$ in height, an oral disc diameter of $14-16 \mathrm{~mm}$, and 52-56 tentacles, found in the Caribbean and Brazil $[40,41,43,44,66,67]$. This species is mentioned as one of the only two valid species of genus Protopalythoa (=Palythoa with liberae polyps) in [66] in the Caribbean.

Furthermore, our obtained DNA sequences from all three molecular markers support lend support to our identification. In [66], Ryland and Lancaster note that Pacific $P$. mutuki is likely closely related to $P$. grandiflora, as they have similar morphologies, while Pacific $P$. heliodiscus may be closely related to $P$. variabilis. Phylogenetic analyses show specimen 1560 sequences to be either very similar to $P$. mutuki (mt $16 \mathrm{~S}$ rDNA, ITS-rDNA) or very closely related to both $P$. mutuki and $P$. tuberculosa (COI). Previously, $P$. mutuki and $P$. tuberculosa have been shown to be very closely related [12], and our phylogenetic results show specimen 1560 is most closely related to Pacific P. mutuki.

Finally, as noted in [62] and [66], P. grandiflora may be a junior synonym of $P$. fusca Duerden 1898 . We also agree with [66] that this species is not synonymous with $P$. mammillosa [21], as Figure 7 in [40] of this species shows a much more "immersae" P. mammillosa colony than as described for $P$. grandiflora or our specimen.

(7) Palythoa grandis (Verrill, 1900) [40]. Specimens: $1559,1561$.
This species, originally assigned to Protopalythoa by Verrill [40], is easy to identify due to its large size (height $=30-36 \mathrm{~mm}$, oral disc diameter $=10-16 \mathrm{~mm}$ ), and deeper habitat (e.g., up to $>12 \mathrm{~m}$ in [40]) than other Caribbean zooxanthellate zoanthids [ $40,43-45,47,48]$. Two specimens $(1556,1561$; Table 1) fit well with this species' characteristics (Figure 1(b)). Furthermore, acquired ITS-rDNA sequences from these specimens were identical or very close to sequences from previously acquired $P$. cf. grandis sequences [70]. It may be that there is more than one species within the $P$. grandis species group, but until such time as revision occurs, we identify specimens 1559 and 1561 as P. grandis.

It should be mentioned that Ryland and Lancaster [66] considered $P$. grandis to be a variant of $P$. variabilis (Duerden 1898), but given $P$. grandis' unique morphology and phylogenetic position, we do not agree with this hypothesis.

(8) Palythoa aff. variabilis (Duerden 1898) [37]. Specimens: 1558, 1564, 1566, and 1567.

Palythoa variabilis was described from Jamaica [37] as a "liberae" [45] Gemmaria (=Protopalythoa) species with polyps 10 to $50 \mathrm{~mm}$ in height and $7 \mathrm{~mm}$ in diameter. This species has 60-80 tentacles, is generally green or brown in color, and has a poorly developed coenenchyme [37, 40, 42, 45]. Palythoa variabilis is distributed throughout the Caribbean and the Atlantic coast of South America (e.g., [67]). [66] noted the morphological similarities between $P$. variabilis and Indo-Pacific P. heliodiscus, but no sequence data exist for this species and the molecular markers used in this study. However, we support the separation of these two species given their distributions in different oceans.

However, four specimens from this study $(1558,1564$ from Hawk Channel, Key West, 1566, 1567 from the aquarium trade) were shown in the phylogenetic results to be similar to previously acquired $P$. heliodiscus sequences. From the ITS-rDNA tree, it appears that the Key West specimens were slightly different from the two aquarium trade specimens. Key West specimens were liberae, with 64-74 tentacles, brown with white patterns on their oral disk, and smaller and less robust than $P$. grandis, and generally fit the description of $P$. variabilis asides from oral disk patterning (Figure 1(a)). On the other hand, the aquarium trade specimens had much brighter oral disk colors, either fluorescent green (1566) or purple (1567), and these are likely a different species from Key West specimens. The original sampling location of these two specimens remains unknown, like many specimens obtained from the aquarium trade [78]. Thus, until $P$. variabilis sequence data as well as localities for specimens 1566 and 1567 are obtained, identification remains open to error, and for this reason we have designated these four specimens as one species group, $P$. aff. variabilis.

(9) Palythoa aff. clavata (Duchassaing 1850) [28]. Specimens: 1562, 1563.

These two specimens were shown through molecular analyses to be closest to $P$. sp. "sakurajimensis" from the Pacific, and did not match with any Atlantic species' sequences. Furthermore, their morphology did not completely match with any hitherto formally described Caribbean zoanthid species, although both specimens did closely resemble images of a species called "brown zoanthid" in 
a recent marine life guidebook [79], having a brown disc with green or blue overtones of $60-12 \mathrm{~mm}$ in diameter and a white center. This "brown zoanthid" has also recently been cited as being similar to Palythoa sp. 265 reported from the Cape Verde Islands [71]. The mt 16S rDNA tree in this study showed that although specimens 1562 and 1563 were somewhat closely related to Palythoa sp. 265, their sequences were not exact matches.

The closest match from taxonomic literature for these two specimens is P. clavata [28] from St Thomas, which is described with polyps approximately 11-14 mm in height, violet or purple oral disk and tentacles, having approximately 60 tentacles, and being smaller than $P$. variabilis [29-32, 37, 40], although [80] stated $P$. clavata and his $P$. variabilis (from Singapore; now likely $P$. heliodiscus) to be very similar. Thus, based on our phylogenetic results and the small amount of past literature dealing with similar specimens, we have designated this group as $P$. aff. clavata here, although they may be an undescribed species. 1580 .

(10) Isaurus tuberculatus Gray 1828 [24]. Specimen:

The single species of Isaurus from this study was easily identified as Isaurus tuberculatus due to its unique morphology with recumbent (nonerct) polyps with tubercules (Figure $1(\mathrm{k})$ ), and as it is considered the only valid species of this genus in the Atlantic (reviewed in [61]). Currently, this species, described from the Caribbean, has a circumtropical distribution, although Indo-Pacific I. tuberculatus is almost certainly a different, sister species, as no other zooxanthellate coral or zoanthid is known to have such a distribution.

Although phylogenetic results showed Isaurus specimens as closely related to Neozoanthus specimens, these two genera are clearly different in morphology and do have phylogenetic differences as well [81].

(11) Terrazoanthus sp. Specimen: 1581.

This specimen was identified as an undescribed member of this new genus, as it was azooxanthellate with sand incrustations, and was not epizoic on other organisms, instead found on boulders (Figure 1(1)), easily distinguishing this genus from other macrocnemic genera. Currently, only two species of Terrazoanthus are described, both from the Galapagos Islands. This specimen is very likely to be an unidentified species given its location, different COI and ITS-rDNA sequences from its congeners, and different morphology (dark brown as opposed to bright red for T. ono $i$ and clear, white or light brown for T. sinnigeri).

\section{Discussion}

4.1. Palythoa and Zoanthus Species Identification. Actual numbers of species in Palythoa and Zoanthus are likely much lower than the numbers of species for each genus described in the literature (currently 218 and 151 species, resp.; according to $[82])[8,9]$, as it has been suggested that many species are actually inadvertent redescriptions due to high levels of intraspecific variation and wide geographic ranges [8, 9]. Despite the comparatively "high" levels of diversity of zoanthid species observed in this study, the numbers of species observed in this and other recent studies (e.g., 5-13 species/region) support the theory of an overall reduction in the actual number of shallow water zoanthid species, as most species appear to be widespread and not endemic to one location.

Although many Palythoa and Zoanthus species have been described from the Caribbean, the true number of valid Palythoa and Zoanthus species for the Caribbean is unknown. From our review of the taxonomic literature (listed in Materials and Methods), there are at least 37 Palythoa (including Protopalythoa) and 11 Zoanthus described species in the Caribbean. However, many of these species have been synonymized, or theorized to be synonyms, and the taxonomic situation for these two common genera is very chaotic [8]. Results from this study demonstrate this as one Zoanthus species group ( $Z$. aff. pulchellus $[1575,1578])$ and two Palythoa species groups $(1562+1563 ; 1566+1567+1558+$ 1564) do not perfectly match with any previous description of species from the Caribbean region.

The morphology of $Z$. sociatus specimens in this study matches well with descriptions given in literature listed in the "Identification" section. However, past problems in accurate species identification in Palythoa and Zoanthus may be inadvertently compounded by molecular investigations of Caribbean species. Our $Z$. sociatus mt $16 \mathrm{~S}$ rDNA sequences completely matched $(=100 \%)$ by Nucleotide BLASTn with DNA sequences of specimens identified as $Z$. sociatus from Brazil (e.g., AY049060, EU348615) by Longo et al. (unpublished), and from Cape Verde [71]. However, these specimens' mt 16S rDNA sequences are also identical with sequences designated Z. pulchellus (EU828762) in [70]. Furthermore, an examination of GenBank records shows that $\mathrm{mt}$ $16 S$ rDNA sequences for specimens identified as $Z$. sociatus by Burnett (AF282933, AF282934; unpublished) in fact are identical to our $Z$. aff. pulchellus group's sequences. It is clear from such results that proper identification of Zoanthus spp. in the Caribbean remains a difficult undertaking.

This confusion clearly demonstrates that a large-scale, multidisciplinary effort to examine brachycnemic zoanthids in the Caribbean is needed to clarify their diversity and to generate an identification key that can allow future researchers to properly identify these common zoanthids. Until species identification protocols of Palythoa and Zoanthus in the Caribbean are stabilized, molecular investigations may add to the confusion, as accurate species identifications will remain problematic.

4.2. Zoanthid Species Diversity in Florida. The results of this study indicate the presence of eleven species or species groups of shallow water zoanthids in Florida; four Zoanthus spp. (Z. sociatus, $Z$. aff. pulchellus, $Z$. pulchellus, and $Z$. solanderi), five Palythoa spp. (P. caribaeorum, P. grandiflora, $P$. grandis, one or more unknown Palythoa species related to $P$. variabilis), and $P$. aff. clavata, as well as one Isaurus (I. tuberculatus), and one undescribed Terrazoanthus species. This number is unexpectedly high given the relatively small number of specimens and the relatively narrow geographic range of this study. However, specimens were collected after numerous observations and dives in the Florida region, and were conducted to collect as many species as possible. 
Results from this and other studies [69-71] suggest that there may not be so much difference in levels of shallow water zoanthid diversity between the Atlantic and the Pacific oceans. This situation is different from that observed in Scleractinia (hard corals) in which Pacific diversity is much higher than Atlantic [83]. Furthermore, in scleractinians, more ancestral groups distinct from Pacific taxa are found in the Atlantic [83]. The similarity in numbers of species of shallow water zoanthids between the Atlantic and Pacific may be due to a combination of factors. First of all, despite being common in many coral reef ecosystems, it appears that most shallow water zoanthid species have wide ranges, and only a few species are known to have narrow ranges (e.g., Z. praelongus Carlgren 1954 [84] known only from western Australia, I. maculatus Muirhead and Ryland 1985 from Fiji, both discussed in [61]). This situation is likely due to brachycnemic zoanthids' long larval stage (up to $170 \mathrm{~d})$ and subsequent high rates of dispersal $[85,86]$. This theory is further supported by the presence of sister species of Zoanthus, Palythoa and Isaurus in the Atlantic and Pacific (shown in Figure 2(d)), which are very likely the result of the formation of the Isthmus of Panama approximately 2.8 to 3.1 million years ago that divided widespread shallow water zoanthid species into two separate populations [87]. Similar transisthmian sister species have been noted in other marine invertebrate taxa, including Alpheus snapping shrimp $[88,89]$. While the possibility that the slow evolution of mtDNA in zoanthids may also be responsible for the lack of divergence between Atlantic and Pacific zoanthid species, the ITS-rDNA results do show species-level differences between sister species from each ocean. Further examination utilizing additional DNA markers should help researchers more clearly understand zoanthid transisthmian evolution.

Currently, there are no zooxanthellate coral species that inhabit both the Atlantic and Indo-Pacific, and although $I$. tuberculatus is described as being distributed in both oceans [61], due to the isolation of these two ocean regions, we feel this is highly unlikely [90]. Thus, the presence of several pairs of Atlantic-Pacific sister species fits with the ecology, reproduction, and phylogenetic data currently available for zoanthids. In the future, it is likely Isaurus tuberculatus will again be split into an Atlantic and Indo-Pacific species.

4.3. DNA Barcoding in Zoanthids. The results of this study also suggest that the utility of mtDNA for the "DNA barcoding" of sister species is not as effective as for most zoanthids in general [91], due to their recent isolation and divergence, and to the fact that benthic cnidarian mtDNA has a very slow rate of evolution [92]. Indeed, most sister species in this study had identical mt $16 \mathrm{~S}$ rDNA and COI sequences. Still, combined with sampling location data (i.e., Atlantic or Pacific), barcoding should allow correct zoanthid species identification, or at least identification to the nearest species group in the case of closely related species. Furthermore, the utility of ITS-rDNA as a phylogenetic marker appears to be high, as resolution in the phylogeny and bootstrap support values in this study were high. However, this marker has multiple intragenomic copies and also potential signals from past hybridization events and/or ancestral polymorphisms in zoanthids $[12,13]$. These potential problems can be overcome with cloning protocols, but these issues make ITSrDNA unusable as a "DNA barcode", which requires single copy markers. However, based on results of previous research $[11-13,15,69,70]$, ITS-rDNA does appear to have high utility as a phylogenetic marker for zoanthids even if it is not useful as a barcode.

4.4. Terrazoanthus Distribution. This paper is the second demonstrating the presence of the genus Terrazoanthus in the Atlantic, after [71], and this genus has now been reported from the eastern Atlantic (Cape Verde), Caribbean (this study), and eastern and central Pacific (Indonesia; T. sp. "yellow polyps" sensu Reimer and Fujii 2010) [74], and this genus has a circumtropical distribution as do Palythoa, Zoanthus, and Isaurus. However, most species in this genus are apparently either not common or inhabit "cryptic" habitats, as asides from T. onoi in [74] most species have only been recorded once or a few times. The Terrazoanthus specimen from this study was found growing in a darkened crevice in the interstices of an artificial jetty composed of boulders in 2 meters of water. The polyps were heavily encrusted with grains of silica sand and were growing upon crustose coralline algae. The environment in which the Terrazoanthus were growing is frequently subjected to heavy wave action and surge. Such environments are not common in the reefs of Florida, excepting man-made structures, and Terrdzoanthus may be rare in Florida.

\section{Conclusions}

This study demonstrates both the difficulties in identifying shallow water zoanthids to the species level, as well as the utility of DNA markers and phylogenetics. Furthermore, despite their regular occurrence in the shallow waters of the Caribbean, it appears that undescribed species potentially exist in this region. In the future, a detailed examination of ITS-rDNA with multiple specimens combined with comparison to the numerous species in literature should help ascertain Caribbean zoanthids' species diversity. The inclusion of specimens from "nonreef" habitats (i.e., docks/pilings, and mangrove swamps) is also needed to obtain a complete picture of zoanthid diversity in this region.

\section{Appendix}

\section{A. Scientific Names and Authorities of Species Mentioned in Text, Figures, and Tables}

P. caesia Dana 1846 [27]

P. caribaeorum (Duchassaing and Michelotti 1860) [30]

P. clavata (Duchassaing 1850) [28]

P. fusca (Duerden 1898) [37]

P. grandiflora (Verrill 1900) [40]

P. grandis (Verrill 1900) [40] 
P. heliodiscus (Ryland and Lancaster 2003) [66]

P. mammillosa (Ellis and Solander 1786) [21]

P. mutuki (Haddon and Shackleton 1891) [35]

P. tuberculosa (Esper 1791) [76]

P. variabilis (Duerden 1898) [37]

H. gracilis (Lwowsky 1913) [46]

I. maculatus Muirhead and Ryland 1985 [61]

I. tuberculatus Gray 1828 [61]

Z. anduzii (Duchassaing and Michelotti 1860) [30]

Z. auricula (Lesueur 1817) [23]

Z. dubius Lesueur 1817 [23]

Z. flos-marinus Duchassaing and Michelotti 1860 [30]

Z. gigantus Reimer and Tsukahara 2006 (in Reimer et al. 2006) [72]

Z. kuroshio Reimer and Ono 2006 (in Reimer et al. 2006) [72]

Z. nobilis Duchassaing and Michelotti 1860 [30]

Z. nymphaeus (Lesueur 1817) [23]

Z. poriticola Pax 1910 [45]

Z. praelongus Carlgren 1954 [84]

Z. proteus Verrill 1900 [40]

Z. pulchellus (Duchassaing and Michelotti 1860) [30]

Z. sansibaricus Carlgren 1900 [73]

Z. sociatus (Ellis 1786) [21]

Z. solanderi Lesueur 1817 [23]

T. onoi Reimer and Fujii 2010 [11]

T. sinnigeri Reimer and Fujii 2010 [11].

\section{Acknowledgments}

The first author was supported in part by the Rising Star Program and the International Research Hub Project for Climate Change and Coral Reef/Island Dynamics (both at the University of the Ryukyus). Drs. E. Hirose (University of the Ryukyus), H. Fukami (Miyazaki University), and M. Costello (University of Auckland) are thanked for their help in discussing transisthmithian evolution.

\section{References}

[1] W. C. Jaap, "The ecology of the south Florida coral reefs: a community profile," United States Fish and Wildlife Services FWS/OBS-82/08, Marine Research Lab, Florida Department of Natural Resources, St. Petersburg, Fla, USA, 1984.

[2] J. H. Hudson, "Growth rates in Montastrea annularis: a record of environmental change in Key Largo Coral Reef Sanctuary, Florida," Bulletin of Marine Science, vol. 31, no. 2, pp. 444-459, 1981.
[3] A. M. Szmant and N. J. Gassman, "The effects of prolonged "bleaching" on the tissue biomass and reproduction of the reef coral Montastrea annularis," Coral Reefs, vol. 8, no. 4, pp. 217224, 1990.

[4] E. A. Shinn, G. W. Smith, J. M. Prospero et al., "African dust and the demise of Caribbean coral reefs," Geophysical Research Letters, vol. 27, no. 19, pp. 3029-3032, 2000.

[5] P. J. Somerfield, W. C. Jaap, K. R. Clarke et al., "Changes in coral reef communities among the Florida Keys, 1996-2003," Coral Reefs, vol. 27, no. 4, pp. 951-965, 2008.

[6] D. A. Palandro, S. Andréfouët, C. Hu et al., "Quantification of two decades of shallow-water coral reef habitat decline in the Florida Keys National Marine Sanctuary using Landsat data (1984-2002)," Remote Sensing of Environment, vol. 112, no. 8, pp. 3388-3399, 2008.

[7] K. P. Sebens, "Autotrophic and heterotrophic nutrition of coral reef zoanthids," in Proceedings of the 3rd International Coral Reef Symposium, vol. 1, pp. 397-404, Miami, Fla, USA, 1977.

[8] W. J. Burnett, J. A. H. Benzie, J. A. Beardmore, and J. S. Ryland, "Zoanthids (Anthozoa, Hexacorallia) from the Great Barrier Reef and Torres Strait, Australia: systematics, evolution and a key to species," Coral Reefs, vol. 16, no. 1, pp. 55-68, 1997.

[9] J. D. Reimer, S. Ono, Y. Fujiwara, K. Takishita, and J. Tsukahara, "Reconsidering Zoanthus spp. diversity: molecular evidence of conspecifity within four previously presumed species," Zoological Science, vol. 21, no. 5, pp. 517-525, 2004.

[10] F. Sinniger, J. I. Montoya-Burgos, P. Chevaldonné, and J. Pawlowski, "Phylogeny of the order Zoantharia (Anthozoa, Hexacorallia) based on the mitochondrial ribosomal genes," Marine Biology, vol. 147, no. 5, pp. 1121-1128, 2005.

[11] F. Sinniger, J. D. Reimer, and J. Pawlowski, "The Parazoanthidae (Hexacorallia: Zoantharia) DNA taxonomy: description of two new genera," Marine Biodiversity, vol. 40, no. 1, pp. 57-70, 2010.

[12] J. D. Reimer, K. Takishita, S. Ono, and T. Maruyama, "Diversity and evolution in the zoanthid genus Palythoa (Cnidaria: Hexacorallia) based on nuclear ITS-rDNA," Coral Reefs, vol. 26, no. 2, pp. 399-410, 2007.

[13] J. D. Reimer, K. Takishita, S. Ono, J. Tsukahara, and T. Maruyama, "Molecular evidence suggesting interspecific hybridization in Zoanthus spp. (Anthozoa: Hexacorallia)," Zoological Science, vol. 24, no. 4, pp. 346-359, 2007.

[14] J. D. Reimer, F. Sinniger, Y. Fujiwara, S. Hirano, and T. Maruyama, "Morphological and molecular characterisation of Abyssoanthus nankaiensis, a new family, new genus and new species of deep-sea zoanthid (Anthozoa: Hexacorallia:Zoantharia) from a north-west Pacific methane cold seep," Invertebrate Systematics, vol. 21, no. 3, pp. 255-262, 2007.

[15] C. Aguilar and J. D. Reimer, "Molecular phylogenetic hypotheses of Zoanthus species (Anthozoa: Hexacorallia) using RNA secondary structure of the internal transcribed spacer 2 (ITS2)," Marine Biodiversity, vol. 40, no. 3, pp. 195-204, 2010.

[16] S. Guindon and O. Gascuel, "A simple, fast, and accurate algorithm to estimate large phylogenies by maximum likelihood," Systematic Biology, vol. 52, no. 5, pp. 696-704, 2003.

[17] F. Rodriguez, J. L. Oliver, A. Marin, and J. R. Medina, "The general stochastic model of nucleotide substitution," Journal of Theoretical Biology, vol. 142, no. 4, pp. 485-501, 1990.

[18] M. Kimura, "A simple method for estimating evolutionary rates of base substitutions through comparative studies of nucleotide sequences," Journal of Molecular Evolution, vol. 16, no. 2, pp. 111-120, 1980.

[19] J. Felsenstein, "Confidence limits on phylogenies: an approach using the bootstrap," Evolution, vol. 39, pp. 783-791, 1985. 
[20] J. Ellis, "An account of the Actinia sociata, or clustered animalflower, lately found on the sea-coasts of the new-ceded islands," Philosophical Transactions of the Royal Society of London, vol. 57, part 2, pp. 428-437, 1768.

[21] J. Ellis and D. Solander, The Natural History of Many Curious and Uncommon Zoophytes, Collected from Various Parts of the Globe, Benjamin White and Son, London, UK, 1786.

[22] J. V. F. Lamouroux, Histoire des Polypiers Coralligènes Flexibles, Vulgairement Nommés Zoophytes, Caen, Impr. de F. Poisson, Caen, France, 1816.

[23] C. A. Lesueur, "Observations on several species of the genus Actinia, illustrated by figures," Journal of the Academy of Natural Sciences of Philadelphia, vol. 1, pp. 149-189, 1817.

[24] J. E. Gray, Spicilegia Zoologica, or Original Figures and Short Systematic Descriptions of New and Unfigured Animals. Part 1, Treuttel, Wurtz and Co., London, UK, 1828.

[25] J. R. C. Quoy and P. Gaimard, Voyage de Découvertes de l'Astrolabe Exécuté par Ordre du Roi, Pendant les Années 18261827-1828-1829, sous le Commandement de M. J. Dumont D'Urville. Volume 4-Zoophytes, J. Tastu, Paris, France, 1833.

[26] C. G. Ehrenberg, "Beiträge zur physiologischen Kenntniss der Corallenthiere im allgemeinen, und besonders des rothen Meeres, nebst einem Versuche zur physiologischen Systematik derselben," Abhandlungen Der Königlichen Akademie Der Wissenschaften Zu Berlin, vol. 1, pp. 225-280, 1834.

[27] J. D. Dana, "United States exploring expedition during the years 1838-1842," Zoophytes, vol. 7, pp. 1-740, 1846-1849.

[28] P. de F. Duchassaing, Animaux Radiaires des Antilles, Plon Fréres, Paris, France, 1850.

[29] H. Milne Edwards, Histoire Naturelle des Coralliaires ou Polypes Proprement Dits, vol. 1, Librairie Encyclopédique de Roret, Paris, France, 1857.

[30] P. de F. Duchassaing and J. Michelotti, Mémoire sur les Coralliaires des Antilles, Imprimerie Royale, Turin, PiedmontSardinia, Italy, 1860.

[31] P. de F. Duchassaing and J. Michelotti, "Mémoire sur les Coralliaires des Antilles," Memorie della Accademia delle Scienze di Torino. 2, vol. 19, pp. 279-365, 1861.

[32] P. Duchassaing and G. Michelotti, Supplément au Mémoiresur les Coralliaires des Antilles, Imprimerie Royale, Turin, Italy, 1864.

[33] J. E. Gray, "Notes on Zoanthinae, with descriptions of some new genera," Proceedings of the Zoological Society of London, vol. 15, pp. 233-240, 1867.

[34] A. Andres, "Le Attinie," Atti dell'Accademia de Lincei, Serie 3 Memorie, vol. 14, pp. 211-673, 1883.

[35] A. C. Haddon and A. M. Shackleton, "The Zoantheae," in A Revision of the British ActIniae. Part II. Reports on the Zoological Collections Made in the Torres Straits by A. C. Haddon, 18881889, 1891, Scientific Transactions of the Royal Dublin Society, Series 2, vol. 4, no. 12, pp. 609-672 and pp. 58-60, 1891.

[36] A. C. Haddon and A. M. Shackleton, "Actiniae: I. Zoantheae," in Reports on the Zoological Collections Made in the Torres Straits by Professor A. C. Haddon, 1888-1889, 1891, Scientific Transactions of the Royal Dublin Society, series 2, vol. 4, no. 13, pp. $673-658$ + pls. $61-64,1891$.

[37] J. E. Duerden, “Jamaican Actiniaria. Part I.-ZZoantheae," Scientific Transactions of the Royal Dublin Society, vol. 6, pp. 329385,1898

[38] E. Jourdan, "Zoanthaires provenant des campagnes du yacht l'Hirondelle (Golfe de Gascogne, Açores, Terre-Neuve)," Résultats des Campagnes Scientifiques Du Prince De Monaco, vol. 8, pp. 1-36, 1895.
[39] J. P. McMurrich, "Report on the Actiniaria collected by the Bahama Expedition of the State University of Iowa, 1893," Bulletin of the Laboratories of Natural History of the State University of Iowa, vol. 4, no. 3, pp. 225-249, 1898.

[40] A. E. Verrill, "Additions to the Anthozoa and Hydrozoa of the Bermudas," Transactions of the Connecticut Academy of Arts and Science, vol. 10, no. 2, pp. 551-572, 1900.

[41] A. E. Verrill, "Additions to the fauna of the Bermudas from the Yale Expedition of 1901, with notes on other species," Transactions of the Connecticut Academy of Arts and Science, vol. 11, no. 1, pp. 15-62, 1901.

[42] J. E. Duerden, "Report on the actinians of Puerto Rico," United States Fishery Commission Bulletin (1900), vol. 20, pp. 321354, 1902.

[43] A. E. Verrill, "The Bermuda Islands Pat IV Geology and paleontology, and part V An account of the coral reefs," Transactions of the Connecticut Academy of Arts and Science, vol. 12, pp. 45-348, 1905.

[44] A. E. Verrill, "Additions to the Anthozoa and Hydrozoa of the Bermudas. Anthozoa," in Zoology of Bermuda, A. E. Verrill, Ed., pp. 551-572, A. E. Verrill, New Haven, Conn, USA, 1907.

[45] F. Pax, "Studien an westindischen Actinien," Zoologische Jahrbücher Supplement, vol. 11, pp. 157-330, 1910.

[46] F. F. Lwowsky, "Revision der gattung Sidisia (Epizoanthus auct.), ein beitrag zur kenntnis der Zoanthiden," Zoologische Jahrbücher für Systematik, Ökologie Und Geographie der Tiere, vol. 34, pp. 557-613, 1913.

[47] F. Pax, "Actiniarien, Zoantharien und Ceriantharien von Curacao," Kungliga Zoologisch Genootschap Natura Artis Magistra, vol. 23, pp. 93-122, 1924.

[48] R. Seifert, "Die Nesselkapseln der Zoantharien und ihre differentialdiagnostische Bedeutung," Zoologische Jahrbücher, vol. 55, pp. 419-500, 1928.

[49] W. Arndt and F. Pax, "Das Zusammenleben von Krustenanemonen und schwämmen im Mittelmeer, mit besonderer Berücksichtigung der Adria," Thalassia, vol. 2, no. 3, pp. 1-34, 1936.

[50] O. Carlgren and J. W. Hedgpath, "Actiniaria, Zoantharia and Ceriantharia from shallow water in the northwestern Gulf of Mexico," Publications of the Institute of Marine Science of the University of Texas, vol. 2, no. 2, pp. 143-172, 1952.

[51] F. Pax and I. Muller, "Zoantharien aus Französisch Westafrika," Bulletin de l'Institut Fondamental de l'Afrique Noire, Serie A, vol. 18, no. 2, pp. 418-458, 1956.

[52] R. K. Trench, "Nutritional potentials in Zoanthus sociathus (Coelenterata, Anthozoa)," Helgoländer Wissenschaftliche Meeresuntersuchungen, vol. 26, no. 2, pp. 174-216, 1974.

[53] M. A. R. Koehl, "Water flow and morphology of zoanthid colonies," in Proceedings of the 3rd International Coral Reef Symposium, vol. 1, pp. 437-444, Miami, Fla, USA, 1977.

[54] R. H. Karlson, "Alternative competitive strategies in a periodically disturbed habitat," Bulletin of Marine Science, vol. 30, pp. 894-900, 1980.

[55] R. H. Karlson, "Reproductive patterns in Zoanthus sp. from Discovery Bay, Jamaica," in Proceedings of the 4th International Coral Reef Symposium, vol. 2, pp. 699-704, Manila, Philippines, 1981.

[56] T. H. Suchanek and D. J. Green, "Interspecific competition between Palythoa caribaeorum and other sessile invertebrates on St. Croix reefs, U.S. Virgin Islands," in Proceedings of the 4th International Coral Reef Symposium, vol. 2, pp. 679-684, Manila, Philippines, 1981.

[57] K. S. Larson and R. J. Larson, "On the ecology of Isaurus duchassaingi (Andres) (Cnidaria: Zoanthidea) from South Water 
Cay, Belize," in The Atlantic Barrier Ecosystems at Carrie Bow Cay, Belize, I: Structure and Communities. Smithsonian Contributions To the Marine Science 1, K. Rutzler and I. G. MacIntyre, Eds., pp. 475-488, Smithsonian, Washington, DC, USA, 1982.

[58] K. P. Sebens, "Intertidal distribution of zoanthids on the Caribbean coast of Panama: effects of predation and dessication," Bulletin of Marine Science, vol. 32, no. 1, pp. 316-335, 1982.

[59] R. H. Karlson, "Disturbance and monopolization of a spatial resource by Zoanthus sociatus ( Coelenterata, Anthozoa)," Bulletin of Marine Science, vol. 33, no. 1, pp. 118-131, 1983.

[60] Y. H. Fadlallah, R. H. Karlson, and K. P. Sebens, "A comparative study of sexual reproduction in three species of Panamanian zoanthids ( Coelenterata: Anthozoa)," Bulletin of Marine Science, vol. 35, no. 1, pp. 80-89, 1984.

[61] A. Muirhead and J. S. Ryland, "A review of the genus Isaurus Gray, 1828 ( Zoanthidea), including new records from Fiji," Journal of Natural History, vol. 19, no. 2, pp. 323-335, 1985.

[62] S. Cairns, C. den Hertog, and C. Arneson, "Class Anthozoa (Corals, anemones)," in Marine Fauna and Flora of Bermuda. A Systematic Guide to the Identification of Marine Organisms, W. Sterrer and C. Schoepfer-Sterrer, Eds., pp. 159-194, John Wiley \& Sons, New York, NY, USA, 1986.

[63] R. H. Karlson, "Size-dependent growth in two zoanthid species: a contrast in clonal strategies," Ecology, vol. 69, no. 4, pp. 1219-1232, 1988.

[64] D. Haywick and E. Mueller, "Sediment assimilation and calcification by the western Atlantic reef zoanthid Palythoa caribaeorum," Bulletin de l'Institut Oceanographique (Monaco), vol. 14, pp. 89-100, 1995.

[65] S. A. Fossa and A. J. Nilsen, The Modern Coral Reef Aquarium, vol. 2, Birgit Schmettkamp, Bornheim, Germany, 1998.

[66] J. S. Ryland and J. E. Lancaster, "Revision of methods for separating species of Protopalythoa (Hexacorallia:Zoanthidea) in the tropical West Pacific," Invertebrate Systematics, vol. 17, no. 3, pp. 407-428, 2003.

[67] S. S. Oigman-Pszczol, M. A. D. Figueiredo, and J. C. Creed, "Distribution of benthic communities on the tropical rocky subtidal of Armação dos Búzios, southeastern Brazil," Marine Ecology, vol. 25, no. 3, pp. 173-190, 2004.

[68] A. Acosta, M. Casas, C. A. Vargas, and J. E. Camacho, "Lista de Zoantharia (Cnidaria: Anthozoa) del Caribe y de Colombia," Biota Colombiana, vol. 6, no. 2, pp. 147-162, 2005.

[69] T. D. Swain, "Phylogeny-based species delimitations and the evolution of host associations in symbiotic zoanthids (Anthozoa, Zoanthidea) of the wider Caribbean region," Zoological Journal of the Linnean Society, vol. 156, no. 2, pp. 223-238, 2009.

[70] T. D. Swain, "Evolutionary transitions in symbioses: dramatic reductions in bathymetric and geographic ranges of Zoanthidea coincide with loss of symbioses with invertebrates," Molecular Ecology, vol. 19, no. 12, pp. 2587-2598, 2010.

[71] J. D. Reimer, M. Hirose, and P. Wirtz, "Zoanthids of the Cape Verde Islands and their symbionts: previously unexamined diversity in the Northeastern Atlantic," Contributions to Zoology, vol. 79, pp. 147-163, 2010.

[72] J. D. Reimer, S. Ono, A. Iwama, K. Takishita, J. Tsukahara, and T. Maruyama, "Morphological and molecular revision of Zoanthus (Anthozoa: Hexacorallia) from Southwestern Japan, with descriptions of two new species," Zoological Science, vol. 23, no. 3, pp. 261-275, 2006.

[73] O. Carlgren, "Ostafrikanische Actinien," Jahrbuch der Hamburgischen Wissenschaftlichen Anstalten, vol. 17, pp. 21-144, 1900.
[74] J. D. Reimer and T. Fujii, "Four new species and one new genus of zoanthids (Cnidaria, Hexacorallia) from the Galápagos Islands," ZooKeys, vol. 42, pp. 1-36, 2010.

[75] J. D. Reimer, S. Ono, J. Tsukahara, and F. Iwase, "Molecular characterization of the zoanthid genus Isaurus (Anthozoa: Hexacorallia) and associated zooxanthellae (Symbiodinium spp.) from Japan," Marine Biology, vol. 153, no. 3, pp. 351363, 2008.

[76] E. J. C. Esper, Der Pflanzenthiere in Ubbildungen nach der Natur. Volume 1, Holy Roman Empire, Nürnberg, Germany, 1791.

[77] A. Erdmann, "Ueber einige neue Zoantheen. Ein Beitrag zur anatomischen und systematischen Kenntnis der Actinien," Jenaische Zeitschrift für Naturwissenschaft, vol. 19, pp. 430488, 1885.

[78] J. R. Deeds, S. M. Handy, K. D. White, and J. D. Reimer, "Palytoxin found in Palythoa sp. zoanthids (Anthozoa, Hexacorallia) sold in the home aquarium trade," PLoS ONE, vol. 6, no. 4, article e18235, 2011.

[79] P. Humann, Reef Creature Identification (Florida Caribbean Bahamas), New World Publications, Jacksonville, Fla, USA, 2002.

[80] A. R. Heider, “Über zwei Zoantheen," Zeitschrift fur Wissenschaftliche Zoologie, vol. 66, part 1, pp. 269-288, 1899.

[81] J. D. Reimer, M. Hirose, Y. Irei, M. Obuchi, and F. Sinniger, "The sands of time: rediscovery of the genus Neozoanthus (Cnidaria: Hexacorallia) and evolutionary aspects of sand incrustation in brachycnemic zoanthids," Marine Biology, vol. 158, no. 5, pp. 983-993, 2011.

[82] D. G. Fautin, Hexacorallians of the World, Kansas Geological Survey, University of Kansas, Lawrence, Kan, USA, 2011, http://geoportal.kgs.ku.edu/hexacoral/anemone2/index.cfm.

[83] H. Fukami, C. A. Chen, A. F. Budd et al., "Mitochondrial and nuclear genes suggest that stony corals are monophyletic but most families of stony corals are not (Order Scleractinia, Class anthozoa, phylum cnidaria)," PLoS ONE, vol. 3, no. 9, article e3222, 2008

[84] O. Carlgren, "Actiniaria and Zoantharia from South and West Australia with comments upon some Actiniaria from New Zealand," Arkiv For Zoologi, vol. 6, pp. 571-595, 1954.

[85] J. S. Ryland, S. de Putron, R. S. Scheltema, P. J. Chimonides, and D. G. Zhadan, "Semper's (zoanthid) larvae: pelagic life, parentage and other problems," Hydrobiologia, vol. 440, pp. 191-198, 2000.

[86] O. Polak, Y. Loya, I. Brickner, E. Kramarski-Winter, and Y. Benayahu, "The widely-distributed Indo-Pacific zoanthid Palythoa tuberculosa: a sexually conservative strategist," Bulletin of Marine Science, vol. 87, no. 3, pp. 605-621, 2011.

[87] A. G. Coates and J. A. Obando, "The geological evolution of the Central American Isthmus," in Evolution and Environment in Tropical America, J. B. C. Jackson, A. F. Budd, and A. G. Coates, Eds., pp. 21-56, University of Chicago Press, Chicago, Ill, USA, 1996.

[88] N. Knowlton, L. A. Weigt, L. A. Solorzano, D. K. Mills, and E. Bermingham, "Divergence in proteins, mitochondrial DNA, and reproductive compatibility across the Isthmus of Panama," Science, vol. 260, no. 5114, pp. 1629-1632, 1993.

[89] S. T. Williams, N. Knowlton, L. A. Weigt, and J. A. Jara, "Evidence for three major clades within the snapping shrimp genus Alpheus inferred from nuclear and mitochondrial gene sequence data," Molecular Phylogenetics and Evolution, vol. 20, no. 3, pp. 375-389, 2001. 
[90] J. D. Reimer, S. Ono, F. Sinniger, and J. Tsukahara, “Distribution of zooxanthellate zoanthid species (Zoantharia: Anthozoa: Hexacorallia) in southern Japan limited by cold temperatures," Galaxea, vol. 10, pp. 57-67, 2008.

[91] F. Sinniger, J. D. Reimer, and J. Pawlowski, "Potential of DNA sequences to identify zoanthids (Cnidaria: Zoantharia)," Zoological Science, vol. 25, no. 12, pp. 1253-1260, 2008.

[92] T. L. Shearer, M. J. H. Van Oppen, S. L. Romano, and G. Wörheide, "Slow mitochondrial DNA sequence evolution in the Anthozoa (Cnidaria)," Molecular Ecology, vol. 11, no. 12, pp. 2475-2487, 2002. 

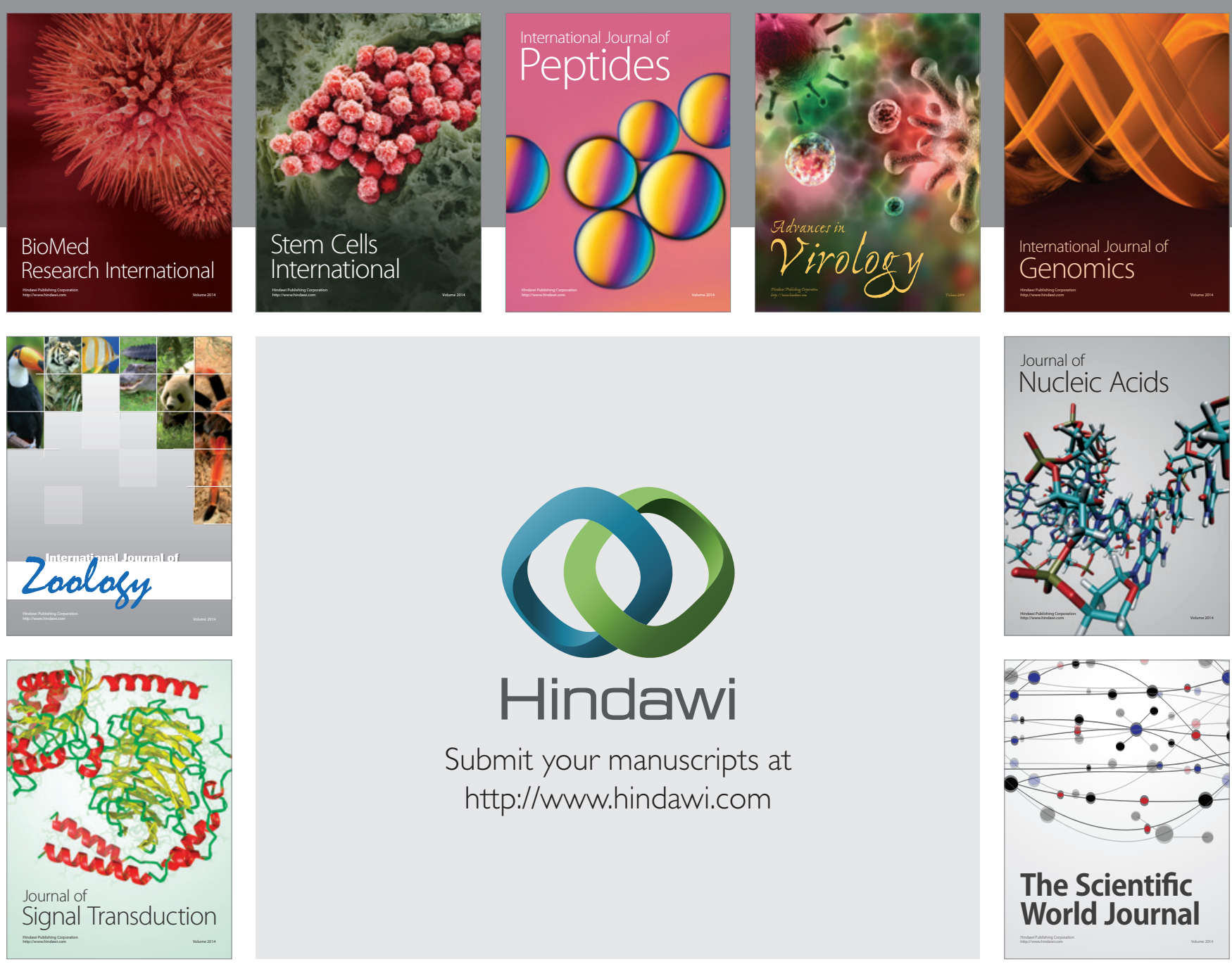

Submit your manuscripts at

http://www.hindawi.com
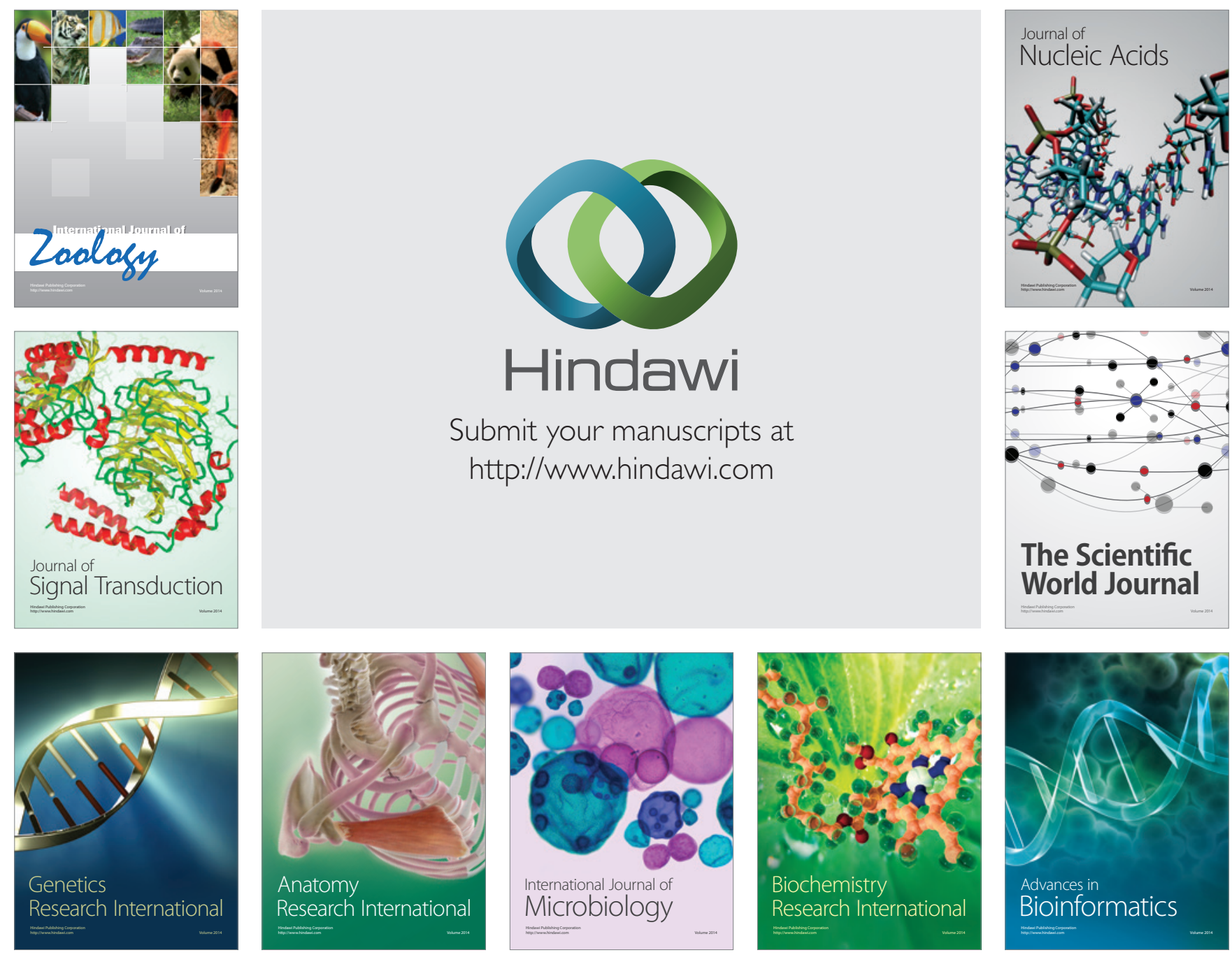

The Scientific World Journal
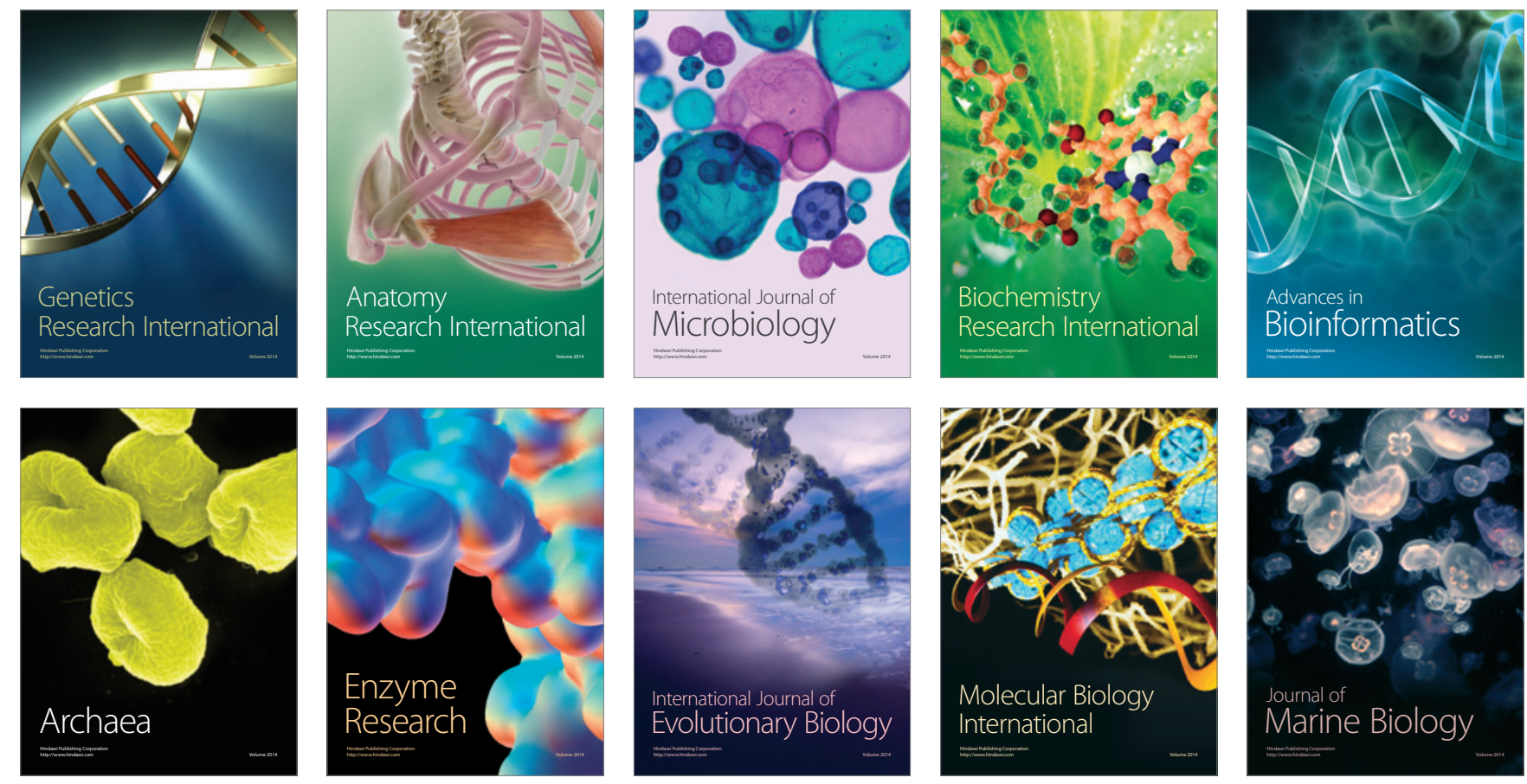